\title{
Inovações em tempos de debate
}

Innovation in challenging times

Maria Isabel da Cunha

Sinto-me privilegiada ao ter o ensaio denominado Inovações pedagógicas: tempos de silêncios e possibilidades de produção analisado por professores e intelectuais do porte de Denise Leite, Elisa Lucarelli, Gaudêncio Frigotto e Newton César Balzan. Reconheço neles uma excepcional condição acadêmica que legitima as suas proposições nesse contexto. Ainda mais, debito a eles boa parte da minha formação, pela inspiração em seus textos e contribuições teóricas. Mas, o que mais me é caro, é ter encontrado neles a inspiração ética e humana com as quais procuro pautar minha ação na pesquisa e na docência.

Dialogar com esses professores sobre o tema das inovações na perspectiva da ruptura paradigmática é, acima de tudo, acolher contribuições que, de forma efetiva, ampliam a temática e a tornam mais atrativa e fascinante.

Tomando a contradição como eixo da possibilidade do processo inovativo, é possível encontrar sua presença nos escritos de meus interlocutores. Acompanha o diálogo a perspectiva dual que caracteriza a contradição, pontuada na relação otimismo e pessimismo, realidade e utopia, ciência e cultura, avaliação somativa e avaliação formativa, teoria e prática, regulação e emancipação, modernidade e pós-modernidade, por exemplo. Esta constatação reafirma que vivemos em tempos de transição e que a possibilidade histórica se apresenta como um desafio intenso para esta e para as próximas gerações.

Foi importante entender nossa fragilidade, saber que não podemos tudo, que somos parte de um todo a navegar em territórios minados de amarras culturais e estruturas de poder. É crucial compreender criticamente nossa condição de educadores num contexto muitas vezes tão adverso. Mesmo assim, é preciso reafirmar a condição da possibilidade do novo. Quanto tempo precisamos para poder afirmar que a esperança venceu $O$ medo? E o que fazer dessa esperança senão tomá-la como apenas mais uma possibilidade?

Viver a possibilidade é o nosso desafio. Inovações que incorporam as contradições, mas não navegam sem rumo. Na provisoriedade enxergam seu lume, acreditam na sua utopia. São exigentes enquanto esforço humano, pois se alicerçam em pilares da complexidade. Não abdicam do sonho, como argumenta Freire (Freire \& Shor, 1986, p.220), "que é a possibilidade de ir além do amanhã sem ser ingenuamente idealista, numa relação dialética entre denunciar o presente e anunciar o futuro".

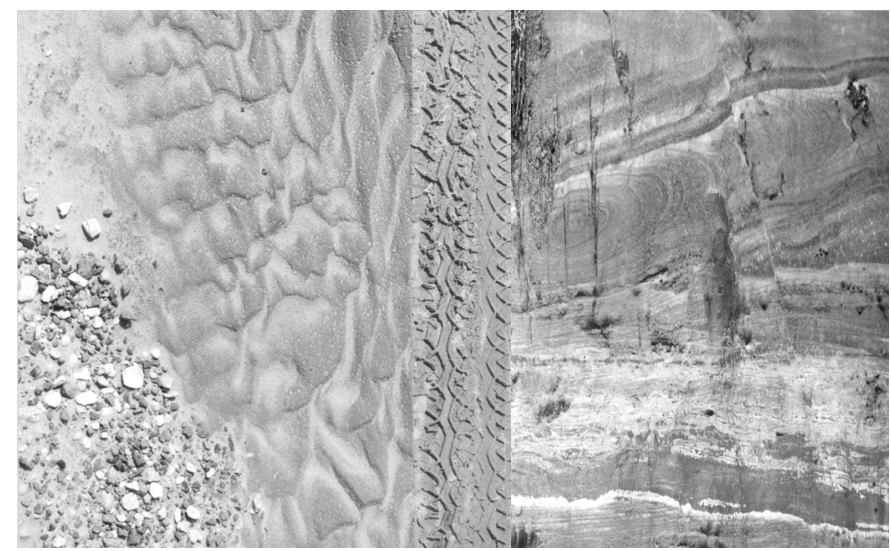

\section{Referência}

FREIRE, P.; SHOR, I. Medo e

FREIRE, P., SHOR, I. Me do professor.

ousadia: O cotidiano Terra, 1986.

Recebido para publicação em 30/04/03. Aprovado para publicação em 14/07/03 